\title{
Gas Sensors Modified with Zeolite Y for Assessing Wine Aroma Compounds
}

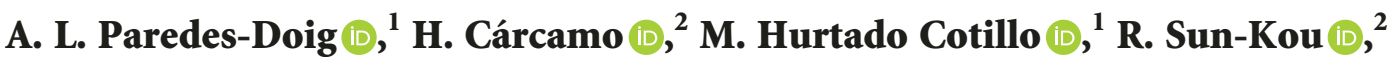 \\ E. Doig-Camino $\mathbb{D}^{\mathbb{3}},{ }^{3}$ G. Picasso $\mathbb{D}^{1},{ }^{1}$ G. Comina $\mathbb{D}^{1},{ }^{1}$ and A. La Rosa-Toro Gómez ${ }^{1}$ \\ ${ }^{1}$ Faculty of Sciences, Universidad Nacional de Ingeniería, Tupac Amaru 210 Av, Rimac, Lima, Peru \\ ${ }^{2}$ Departament of Sciences, Section of Chemistry, Pontificia Universidad Católica del Perú, Av. Universitaria 1801, \\ San-Miguel, Lima 32, Peru \\ ${ }^{3}$ Departament of Sciences, Section of Mathematic, Pontificia Universidad Católica del Perú, Av. Universitaria 1801, \\ San-Miguel, Lima 32, Peru \\ Correspondence should be addressed to A. L. Paredes-Doig; anludoig@gmail.com
}

Received 10 January 2019; Revised 9 May 2019; Accepted 11 July 2019; Published 11 September 2019

Academic Editor: Jean-Marie Nedelec

Copyright (@ 2019 A. L. Paredes-Doig et al. This is an open access article distributed under the Creative Commons Attribution License, which permits unrestricted use, distribution, and reproduction in any medium, provided the original work is properly cited.

\begin{abstract}
The present work develops a MOS-based e-nose with sensors modified with zeolite $\mathrm{Y}$. For this purpose, the following $\mathrm{SnO}_{2}$ doped with $\mathrm{Pd}$ and/or Pt have been prepared: $\left.\mathrm{M} 1\left((0.25 \mathrm{Pd} / 0.75 \mathrm{Pt}) / \mathrm{SnO}_{2}\right), \mathrm{M} 2\left((0.50 \mathrm{Pd} / 0.50 \mathrm{Pt}) / \mathrm{SnO}_{2}\right), \mathrm{M} 3((0.75 \mathrm{Pd} / 0.25 \mathrm{Pt}) / \mathrm{SnO})_{2}\right)$, $\mathrm{Pd} / \mathrm{SnO}_{2}$, and $\mathrm{Pt} / \mathrm{SnO}_{2}$, at the total concentrations of the noble metals of $0.1 \%$ and $0.2 \%$ for use in gas sensors and be part of the electronic nose. Then, the sensors were assembled with the oxides using the screen printing method. Different electronic noses of four sensors were prepared by combining tin oxides doped with palladium and/or platinum and zeolite Y. The physicochemical characterization of oxides using FRX, FTIR, sorption of $\mathrm{N}_{2}$, and RAMAN has been performed. Measurements for the detection of wine volatile compounds such as ethanol, methanol, 1-phenyl ethanol, propionic acid, and acetic acid were carried out with these sensors located in a gas chamber and using a program that includes the Labview software, which serves to automate the sensing process. It was found that the sensors modified with zeolite were the ones that in general had higher detections of volatile compounds and PCAs showed positive correlations only for ethanol and the mixture of ethanol at $12 \%$ and methanol at $3 \%$. This is related to better detection of these sensors.
\end{abstract}

\section{Introduction}

The sense of smell results from a series of specific and nonspecific molecular surveys that can be used to measure the quality of food, beverages, etc. [1]. In few cases, the receptors are selective; that is, they are specific for some particular type of molecule. In most cases, the odors are perceived by nonspecific interactions. Electronic noses have been developed to mimic this nonspecific recognition. The e-nose sensors are based on different types of materials. For example, MOS (metal-oxide semiconductor) measures concentrations of different compounds such as VOCs (volatile organic compounds) by a variation in their electrical resistance. These sensors work with two characteristics: the receptivity (where the adsorption of the compound is included) and the transduction (to translate the signal). These oxides are more used than other materials for the development of sensors [2].

As mentioned above, until now, we try to imitate the sense of smell by constructing e-noses based on the criterion of a nonspecific perception. However, single molecule detection requires specific recognition in the case of sample differentiation. For instance, the food industry needs to detect if the product is spoiled, adulterated, etc. For this reason, we consider not only the base material of the sensor but also some modification that allows improving its selectivity. From this, our objective is to modify sensors of $\mathrm{SnO}_{2}$-based composites with zeolites in order to eliminate 
the passage of some compounds to the $\mathrm{SnO}_{2}$ surface of the sensor and allow the detection of a target molecule, such as ethanol.

\section{Materials and Methods}

2.1. Oxides Preparation. The following solutions were prepared for preparation of $0.1 \%$ doped tin oxide with mixture platinum and palladium:

2.1.1. Platinum Salt Solution and Palladium Chloride. In a $100 \mathrm{~mL}$ beaker, an amount of $\mathrm{H}_{2} \mathrm{Cl}_{6} \mathrm{Pt}$ and $\mathrm{PdCl}_{2}$ was dissolved with $20 \mathrm{~mL}$ of $0.005 \mathrm{M} \mathrm{HCl}$.

2.1.2. $\mathrm{SnCl}_{2}$ Solution. In a $100 \mathrm{~mL}$ beaker, a mass of $\mathrm{SnCl}_{2}$ was dissolved with $20 \mathrm{~mL}$ of $0.005 \mathrm{M} \mathrm{HCl}$. In a $300 \mathrm{~mL}$ beaker, $100 \mathrm{~mL}$ of $0.005 \mathrm{M} \mathrm{HCl}$ and $3 \mathrm{~g}$ of $\mathrm{SnO}_{2}$ were added together with the platinum salt solution, kept at $30^{\circ} \mathrm{C}$ for 15 min under constant stirring. Subsequently, the $\mathrm{SnCl}_{2}$ solution was added and stirred for $50 \mathrm{~min}$ at $30^{\circ} \mathrm{C}$. The resulting mixture was filtered with Whatman No. 42 paper, followed by washing it with $0.005 \mathrm{M} \mathrm{HCl}$ and then with water in order to eliminate the chloride ions. The solid sample was dried at $80^{\circ} \mathrm{C}$ for $24 \mathrm{~h}$. Subsequently, it was calcined at $400^{\circ} \mathrm{C}$ for $1 \mathrm{~h}$. This procedure has been used in previous researches $[2,3]$.

2.2. Sensors Preparation. A template was formed with the adhesive tape to define the area that would cover the film on the surface of two alumina plates. Subsequently, 0.1 gram of doped tin oxide was combined with $0.1 \%$ Pd or Pt with $0.02 \mathrm{~g}$ of ethylcellulose and $32 \mu \mathrm{L}$ of $\alpha$-terpineol, forming a paste, which was deposited on the two substrates of alumina, and then a heat treatment was carried out in the oven for $15 \mathrm{~min}$ at $60^{\circ} \mathrm{C}$.

2.3. Zeolite Y Activation. Activation of zeolite $\mathrm{Y}$ was performed by three ion exchanges, using $600 \mathrm{~mL}$ of $\left(\mathrm{NH}_{4}\right) \mathrm{NO}_{3}$ $1 \mathrm{M}$ with 6 grams of zeolite. The $\left(\left(\mathrm{NH}_{4}\right) \mathrm{NO}_{3}\right.$ solution containing the zeolite was placed in the two-neck balloon and brought to the reflux system at $60^{\circ} \mathrm{C}$ for $24 \mathrm{~h}$ under constant agitation. The product obtained was centrifuged at $4000 \mathrm{rpm}$ for $25 \mathrm{~min}$, and the aqueous part was decanted. This procedure was repeated three times. After the ionic exchanges, the solid product was washed with distilled water and dried in the oven at $100^{\circ} \mathrm{C}$ for $16 \mathrm{~h}$. The solid was calcined in the muffle using a heating branch of $350^{\circ} \mathrm{C}$ for $2 \mathrm{~h}$ and $500^{\circ} \mathrm{C}$ for $3 \mathrm{~h}$.

2.4. Sensors Modified with Zeolite Y. In a beaker containing $0.05 \mathrm{~g}$ of tin oxide doped with $\mathrm{Pt}$ or with $\mathrm{Pd}, 0.01 \mathrm{~g}$ of ethylcellulose and $16 \mu \mathrm{L}$ of $\alpha$-terpineol were added, these substances were mixed uniformly to form a paste, which is deposited on a surface of alumina containing two gold electrodes, and then the entire assembly is calcined at $600^{\circ} \mathrm{C}$ for $10 \mathrm{~min}$ using a heating ramp of $3^{\circ} \mathrm{C} / \mathrm{min}$.
In order to prepare a thin layer of zeolite Y, 1,2-propanediol is used as a solvent following the procedure described by Vilaseca et al. [4]. Each mixture was constantly stirred until the zeolite is dispersed in the solvent. Later, with the help of a micropipette, a small quantity is extracted, which is deposited by microdripping on the surface of the tin oxide previously placed on the alumina sheet. Subsequently, we evaluated the sensor signal obtained in the presence of volatile compounds.

2.5. Localized Sensors in the Camera. The alumina plate including the printed electrodes is placed on a steel plate which in turn acts as a heater, replacing the four sensor heaters. This replacement allows a homogeneous heating. The way to obtain a homogeneous temperature is an innovative element, given that former sensors had its own resistance. This means a lower cost in terms of the heating process.

\section{Results and Discussion}

Table 1 shows the nomenclature of the oxides prepared. Ten oxides were obtained from different proportions of palladium and platinum over tin oxide.

3.1. Characterization of Oxides Prepared. From the FTIR (Figures 1-3), four signals can be seen that are approximately $700,665,620$, and $547 \mathrm{~cm}^{-1}$ corresponding to vibrations of stretching of the $\mathrm{O}-\mathrm{Sn}$ and vibrations of flexion of the O-Sn-O [5]. Then, you can see a shoulder around $3400 \mathrm{~cm}^{-1}$ that can be attributed to the $\mathrm{O}-\mathrm{H}$ signal coming from the adsorbed water, which can be there due to moisture in the environment. As mentioned above, the samples were calcined at $400^{\circ} \mathrm{C}$ and according to data reported in other studies [6], when the tin oxide is calcined at temperatures higher than $300^{\circ} \mathrm{C}$ occurs a division of the recorded band at $700 \mathrm{~cm}^{-1}$, resulting in a division of four bands. We can consider that this range is also affected by doping, but apparently it is exclusively related to calcination temperature.

The band at $1615 \mathrm{~cm}^{-1}$ corroborates the presence of the hydroxyl group due to sample moisture. Apparently, the palladium and platinum charges in the tin oxide are not composing any bond or distorting the bonds of the tin oxide.

Table 2 shows that prepared oxides have low surface area values, which is a characteristic of many metal oxides. M1 $0.1 \% / \mathrm{SnO}_{2}$ and $\mathrm{M} 20.1 \% / \mathrm{SnO}_{2}$ have the largest surface area. All the samples show almost null microporosity. This greatest surface area could be related to better detection. These materials show very low porosity.

According to the International Union Pure and Applied Chemistry (IUPAC), classification isotherms (Figures 4 and 5) are of type IV with a hysteresis loop of type H1, which is characteristic of solids with pores of the cylindrical type.

As previously stated and observing that for low relative pressure values $\left(P / P_{0}\right)$, the adsorbed gas volume in the isotherms starts from zero, we can conclude that microporosity is practically nonexistent in these oxides. The shape 
TABLE 1: Nomenclature of oxides prepared.

\begin{tabular}{|c|c|}
\hline Nomenclature & Description \\
\hline $0.1 \% \mathrm{Pd} / \mathrm{SnO}_{2}$ & Tin oxide doped with $0.1 \%$ palladium \\
\hline $0.1 \% \mathrm{Pt} / \mathrm{SnO}_{2}$ & Tin oxide doped with $0.1 \%$ platinum \\
\hline $0.2 \% \mathrm{Pd} / \mathrm{SnO}_{2}$ & Tin oxide doped with $0.2 \%$ palladium \\
\hline $0.2 \% \mathrm{Pt} / \mathrm{SnO}_{2}$ & Tin oxide doped with $0.2 \%$ platinum \\
\hline $\begin{array}{l}\mathrm{M} 10.1 \% / \\
\mathrm{SnO}_{2}\end{array}$ & $\begin{array}{l}\text { Tin oxide doped with a mixture of palladium and } \\
\text { platinum }(0.25 \mathrm{Pd} / 0.75 \mathrm{Pt}) \text { at } 0.1 \% \text { of metals in its } \\
\text { entirety }\end{array}$ \\
\hline $\begin{array}{l}\mathrm{M} 20.1 \% / \\
\mathrm{SnO}_{2}\end{array}$ & $\begin{array}{l}\text { Tin oxide doped with a mixture of palladium and } \\
\text { platinum }(0.50 \mathrm{Pd} / 0.50 \mathrm{Pt}) \text { at } 0.1 \% \text { of metals in its } \\
\text { entirety }\end{array}$ \\
\hline $\begin{array}{l}\mathrm{M} 30.1 \% / \\
\mathrm{SnO}_{2}\end{array}$ & $\begin{array}{c}\text { Tin oxide doped with a mixture of palladium and } \\
\text { platinum }(0.75 \mathrm{Pd} / 0.25 \mathrm{Pt}) \text { at } 0.1 \% \text { of metals in its } \\
\text { entirety }\end{array}$ \\
\hline $\begin{array}{l}\mathrm{M} 10.2 \% / \\
\mathrm{SnO}_{2}\end{array}$ & $\begin{array}{l}\text { Tin oxide doped with a mixture of palladium and } \\
\text { platinum }(0.25 \mathrm{Pd} / 0.75 \mathrm{Pt}) \text { at } 0.2 \% \text { of metals in its } \\
\text { entirety }\end{array}$ \\
\hline $\begin{array}{l}\mathrm{M} 20.2 \% / \\
\mathrm{SnO}_{2}\end{array}$ & $\begin{array}{l}\text { Tin oxide doped with a mixture of palladium and } \\
\text { platinum }(0.50 \mathrm{Pd} / 0.50 \mathrm{Pt}) \text { at } 0.2 \% \text { of metals in its } \\
\text { entirety }\end{array}$ \\
\hline $\begin{array}{l}\mathrm{M} 3 \text { 0.2\%/ } \\
\mathrm{SnO}_{2}\end{array}$ & $\begin{array}{l}\text { Tin oxide doped with a mixture of palladium and } \\
\text { platinum }(0.75 \mathrm{Pd} / 0.25 \mathrm{Pt}) \text { at } 0.2 \% \text { of metals in its } \\
\text { entirety }\end{array}$ \\
\hline
\end{tabular}

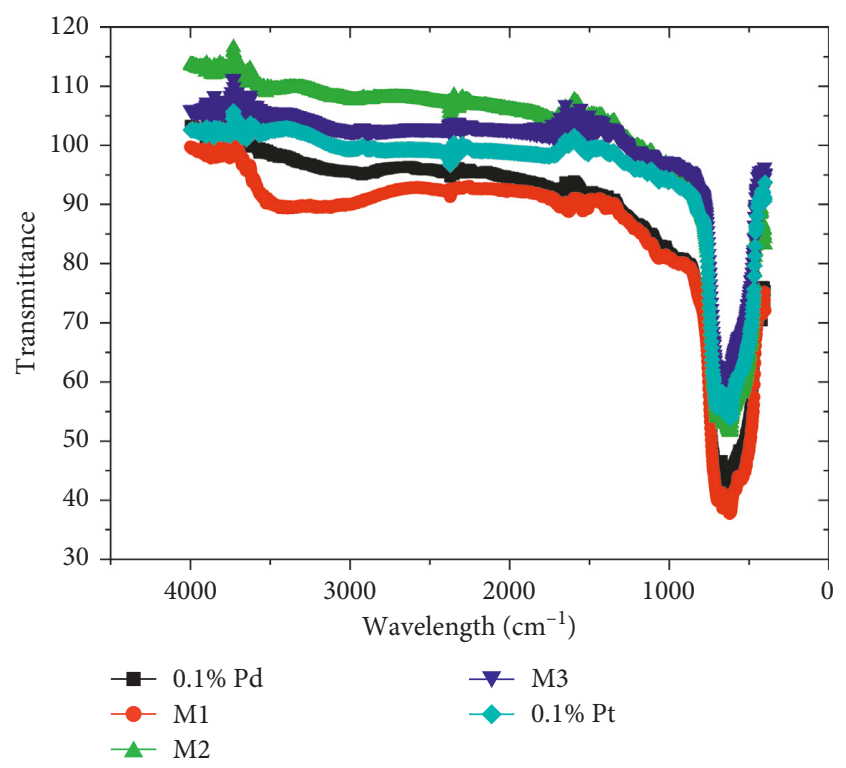

Figure 1: FTIR for oxides doped to $0.1 \%$.

of the isotherms is very similar, with slight variations in the desorption branch. For this reason, if the three isotherms are superimposed, they practically follow the same shape. Therefore, it can be affirmed that the percentage of doping practically does not influence the structure.

It is well known that $\mathrm{SnO}_{2}$ has a tetragonal structure with six atoms ( $2 \mathrm{Sn}$ and $4 \mathrm{O}$ ) per unit cell [7]. Cell atoms of 6 units give a total of 18 branches for the vibratory modes in the first Brillouin zone. From Figures 6 and 7 showing the RAMAN spectra, the vibration frequencies are observed at 476, 638, and $782 \mathrm{~cm}^{-1}$ (e.g., A1g and B2g).

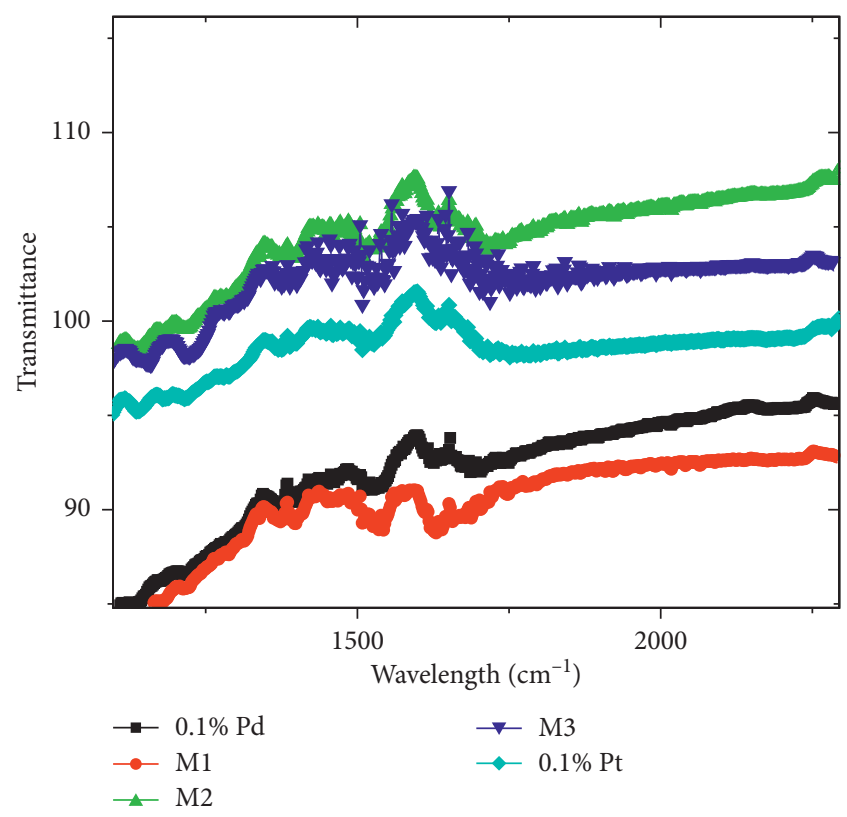

FIgURE 2: FTIR of $1000-2500 \mathrm{~cm}^{-1}$ range for oxides to $0.1 \%$.

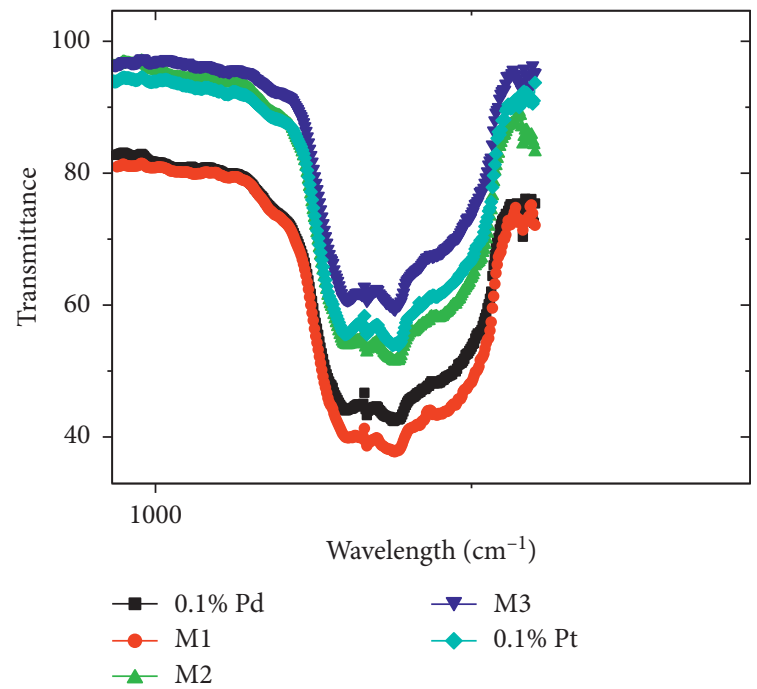

FIgURE 3: FTIR of $1000-0 \mathrm{~cm}^{-1}$ range for oxides to $0.1 \%$.

If there are no changes in the spectrum, like other peaks, it may be due to the little disorder in the $\mathrm{SnO}_{2}$ that exists when low percentages of $\mathrm{Pd}$ and/or $\mathrm{Pt}$ are incorporated. Among the possible ways in which palladium and platinum can be found is that of metal-oxide clusters [8]. If so, they could be identified by RAMAN spectroscopy. However, it did not occur because they are found as zero-valent metals.

Palladium has an ion ratio ( $86 \mathrm{~A})$ which is larger than the platinum one $(80 \mathrm{~A})$ so if it were in a higher concentration, we could observe a disorder generated in the tin oxide network.

This would be corroborated by the decrease in the intensity of the palladium peaks [9].

Using the FRX technique, palladium and platinum have been found in samples of tin oxide that are only doped with 
Table 2: Surface area of $\mathrm{SnO}_{2}$ doped with Pd and/or Pt.

\begin{tabular}{lccc}
\hline Sample & Surface area $\left(\mathrm{m}^{2} / \mathrm{g}\right)$ & Microporous area $\left(\mathrm{m}^{2} / \mathrm{g}\right)$ & Mesoporous area $\left(\mathrm{m}^{2} / \mathrm{g}\right)$ \\
\hline $0.1 \% \mathrm{Pt} / \mathrm{SnO}_{2}$ & 7 & - & 7 \\
$\mathrm{M} 10.1 \% / \mathrm{SnO}_{2}$ & 11 & - & 11 \\
$\mathrm{M} 20.1 \% / \mathrm{SnO}_{2}$ & 12 & - & 12 \\
$\mathrm{M} 30.1 \% / \mathrm{SnO}_{2}$ & 7 & 0.5 & 7 \\
$0.1 \% \mathrm{Pd} / \mathrm{SnO}_{2}$ & 7.5 & - & 7.5 \\
$0.2 \% \mathrm{Pt} / \mathrm{SnO}_{2}$ & 7.5 & - & 7 \\
$\mathrm{M} 10.2 \% / \mathrm{SnO}_{2}$ & 7 & - & 8.7 \\
$\mathrm{M} 20.2 \% / \mathrm{SnO}_{2}$ & 8.7 & 0.5 & 7 \\
$\mathrm{M} 30.2 \% / \mathrm{SnO}_{2}$ & 7.5 & - & 8 \\
$0.2 \% \mathrm{Pd} / \mathrm{SnO}_{2}$ & 8 & & \\
\hline
\end{tabular}

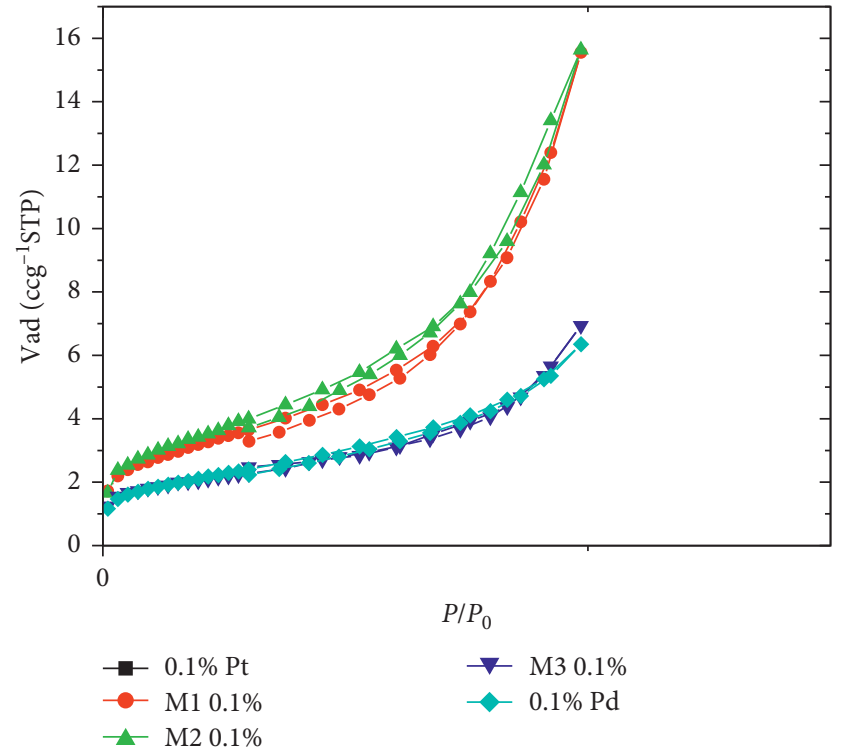

FIgURE 4: Adsorption-desorption isotherms of $\mathrm{N}_{2}$ for oxides of $0.1 \%$.

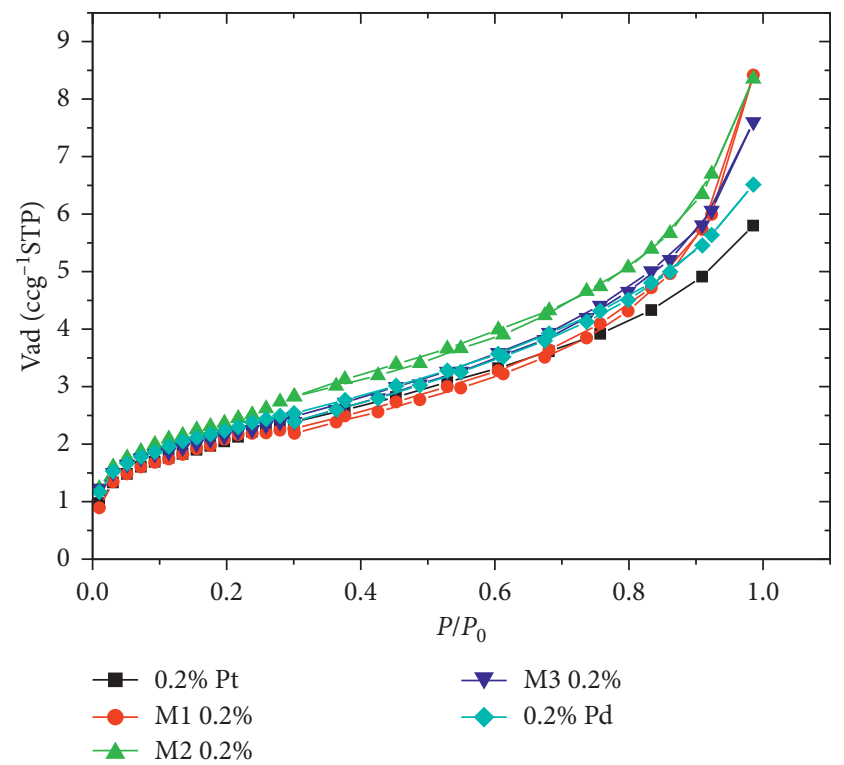

Figure 5: Adsorption-desorption isotherms of $\mathrm{N}_{2}$ for $0.2 \%$ oxides.

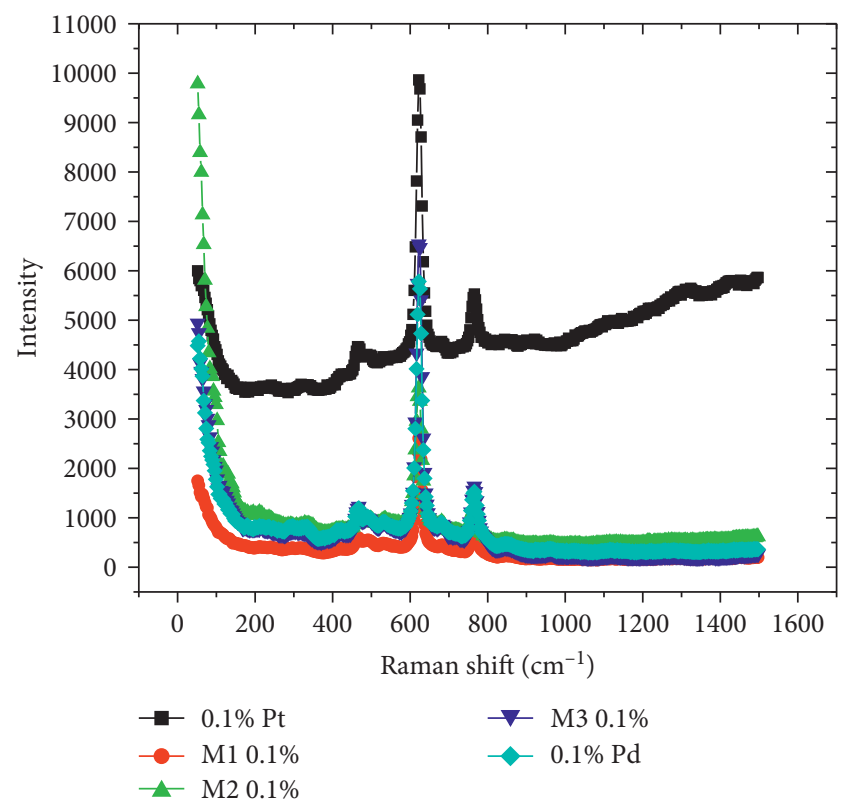

Figure 6: RAMAN spectra of $\mathrm{SnO}_{2}$ doped at $0.1 \% \mathrm{Pd}$ and/or Pt.

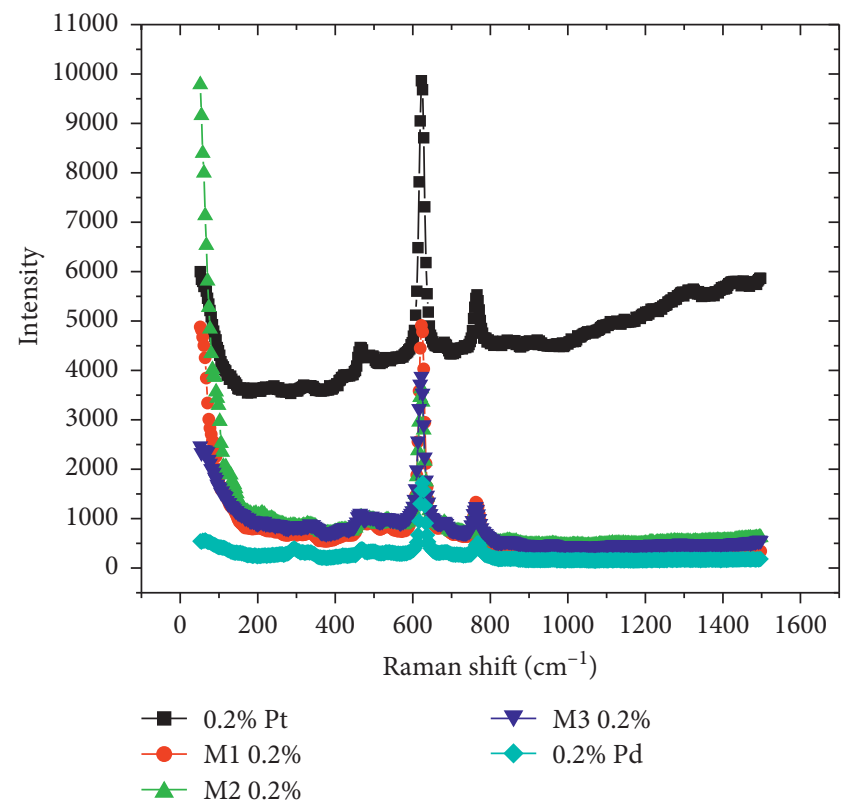

FIgURE 7: RAMAN spectrum of the $\mathrm{SnO}_{2}$ doped at $0.2 \% \mathrm{Pd}$ and/or Pt. 
palladium and platinum. Although palladium and platinum were observed in $\mathrm{M} 1$, the other samples only registered one of these elements. It is possible that the platinum signal can no longer be seen at concentrations lower than $0.05 \%$ or an overlap of the palladium spectrum is also occurring with it. It was possible to identify transitions $\mathrm{L} 1(11-0711 \mathrm{eV}) y \mathrm{~L} 2$ $(9.4427 \mathrm{eV})$ for platinum content and transition KL2 (21$020 \mathrm{eV}) y \mathrm{KL} 3(21.177 \mathrm{eV})$ for palladium.

\subsection{Selection of Samples (Wine Compounds) and Sensing} Process. In a previous study, and in order to select the samples, Peruvian wines were analyzed with gas chromatography (GC). The findings showed that the compounds that characterized the wine aroma were ethanol, 1 phenyl ethanol, and propanoic acid, which were selected due to their highest average concentrations. In winemaking, acetic acid was selected as the most important product of the process of fermentation.

In this study, the Agilent Technologies 7890A gas chromatograph coupled to the Agilent Technologies 5975 selective mass detector and HP-FFAP polar capillary column $(30 \mathrm{~m} \times 250 \mu \mathrm{m} \times 0.25 \mu \mathrm{m})$ were applied for the detection of volatiles.

The sensing process used a static system. Vacuum was applied in an airtight bubbler, and steam was extracted from the sample, which was carried by the pneumatic system to the gas chamber, where the sensor array was located. Then, applying a data acquisition card, the detection was monitored on the sensors by a computer. There, we observed the voltage variation for each sensor while they were in contact with the sample.

3.3. Sensitivity of Sensors. Sensitivity is measured by calculating the difference between the two signals, the baseline signal, and the signal of the plateau.

Sensitivity of wine aroma compounds is measured following these steps:

(a) The sample is placed in a container

(b) Vacuum is made with a pump and the aroma compound (sample) is carried through a pneumatic system

(c) The sample reaches the sensor surface and is detected

Table 3 shows voltage values when the aroma compound was detected for each sensor.

The order of detection in most of the cases is as follows (considering that sensors at $0.1 \%$ are the most stable): mix $12 \%$ ethanol $/$ methanol $3 \%>12 \%$ ethanol $>$ propionic acid $>3 \%$ methanol $>$ acetic acid $>1$ phenyl ethanol.

Most of the cases show that the mixture of ethanol and methanol obtains higher values of voltage than the sum of the two detections, so it must be said that a synergic effect is occurring.

3.4. Results of the Principal Components Analysis (PCA) for the E-Noses of the Sensors Composed by $\mathrm{SnO}_{2}$ Doped with
Palladium and/or Platinum. Differentiation of Volatile Compounds by PCA. The data obtained by the sensitivity measurements using electronic noses with composite sensors were processed using the principal component analysis (PCA).

Figures 8-11 show the results of this multivariate method.

Tin oxide doped with a mixture of palladium and platinum shows results as good as those obtained from doped oxides with platinum. This mixture implies a cost reduction because platinum is more expensive than palladium.

Previously, sensors doped with palladium and platinum were used in order to increase the active sites for the detection of the substance to be analyzed. However, the platinum, which shows the best results, is very expensive. So we try to mix it with palladium, which is less expensive. In order to find a composite with better sensorial properties, we experimented with mixtures of palladium and platinum at different percentages (M1, $\mathrm{M} 2$, and M3).

Mixture $\mathrm{M} 2$ at $0.1 \%$ and $0.2 \%$ showed sensorial properties similar to $\mathrm{Pt} / \mathrm{SnO}_{2}$ at $0.1 \%$. In addition, $\mathrm{PCA}$ and the total variance of the PCAs corroborated the results mentioned above.

For PCA mixtures at $0.2 \%$, the results are not as good as the former PCAs, but it tends to a parabolic drift (displacement of the points of the same sample), which is not common.

The correlations of the data tend to zero, as well as the squared cosines. Both indicate the independence of the variables. Therefore, the samples of wine volatile compounds are different, and the objective of replacing sophisticated techniques such as gas chromatography is achieved basing on PCA results and e-nose device.

3.5. Measurement of Wine Volatile Compounds of the Sensors Modified with Zeolite Y. The use of zeolite Y to modify the sensors is a novel contribution for this research.

It is important to mention that sensors modified with zeolite $\mathrm{Y}$ allow the differentiation and/or transformation of compounds of the same mixture.

In this way, the system would have two parts: a sensor or sensing element $\left(\mathrm{SnO}_{2}\right)$ and the transforming element in order to modify or restrict the composition of the gas under analysis, so that it is ready to interact with the sensor element [10].

The zeolites are composed of a tetrahedron structure $\mathrm{TO}_{4}(T=\mathrm{Si}, \mathrm{Al}$, etc.). The tetrahedral units are joined by a distribution of oxygen atoms to form a three-dimensional skeletal structure of crystalline porous or spongy alumina silicate. The T-O-T joints result in a variety of rings that originate zeolite boxes and channels with different sizes of windows. The use of zeolites in the field of sensors is often employed to improve sensitivity and selectivity, using preferably the adsorption process. The pore size, ion conductivity, adsorption, and catalytic selectivity can be modified by ion exchanges with different cations [11]. 
TABle 3: Sensitivity of sensors based on oxides prepared.

\begin{tabular}{|c|c|c|c|c|c|c|c|c|c|c|}
\hline Compounds & $\begin{array}{c}0.1 \% \\
(\mathrm{Pt})\end{array}$ & $\begin{array}{c}\mathrm{M} 1 \\
0.1 \%\end{array}$ & $\begin{array}{c}\mathrm{M} 2 \\
0.1 \%\end{array}$ & $\begin{array}{c}\text { M3 } \\
0.1 \%\end{array}$ & $\begin{array}{l}0.1 \% \\
(\mathrm{Pd})\end{array}$ & $\begin{array}{c}0.2 \% \\
(\mathrm{Pt})\end{array}$ & $\begin{array}{c}\mathrm{M} 1 \\
0.2 \%\end{array}$ & $\begin{array}{c}\mathrm{M} 2 \\
0.2 \%\end{array}$ & $\begin{array}{c}\text { M3 } \\
0.3 \%\end{array}$ & $\begin{array}{l}0.2 \% \\
(\mathrm{Pd})\end{array}$ \\
\hline Ethanol 12\% (et) & 2 & 0.75 & 1.5 & 0.3 & 0.25 & 0.2 & 0.5 & 2.5 & 0.55 & 0.2 \\
\hline Methanol 3\% (met) & 0.5 & 0.4 & 0.9 & 0.35 & 0.4 & 0.1 & 0.25 & 1.4 & 0.25 & 0.1 \\
\hline $\begin{array}{l}\text { Mixture (ethanol 12\%/methanol 3\%) } \\
\text { (et12met3) }\end{array}$ & 0.75 & 1.8 & 2.8 & 1.2 & 0.5 & 0.35 & 0.8 & 3.2 & 0.8 & 0.35 \\
\hline 1 Phenyl etanol $(f)$ & 0.2 & 0.18 & 0.4 & 0.25 & 0.05 & 0 & 0.2 & 1.2 & 0.2 & 0 \\
\hline Propionic acid $(p)$ & 0.7 & 0.55 & 0.95 & 0.55 & 0.1 & 0.05 & 0.2 & 1.6 & 0.2 & 0 \\
\hline Acetic acid $(a)$ & 0.6 & 0.25 & 0.5 & 0.25 & 0.1 & 0.05 & 0.15 & 1.1 & 0.15 & 0 \\
\hline
\end{tabular}

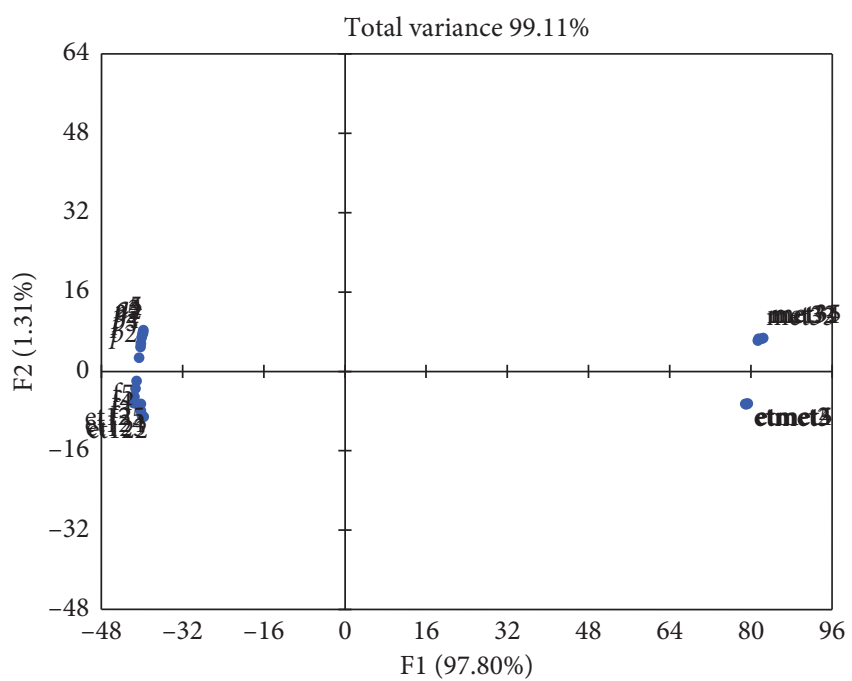

Figure 8: PCA of wine volatile compounds obtained using an e-nose with sensors doped with palladium and platinum at $0.1 \%$ and $0.2 \%$.

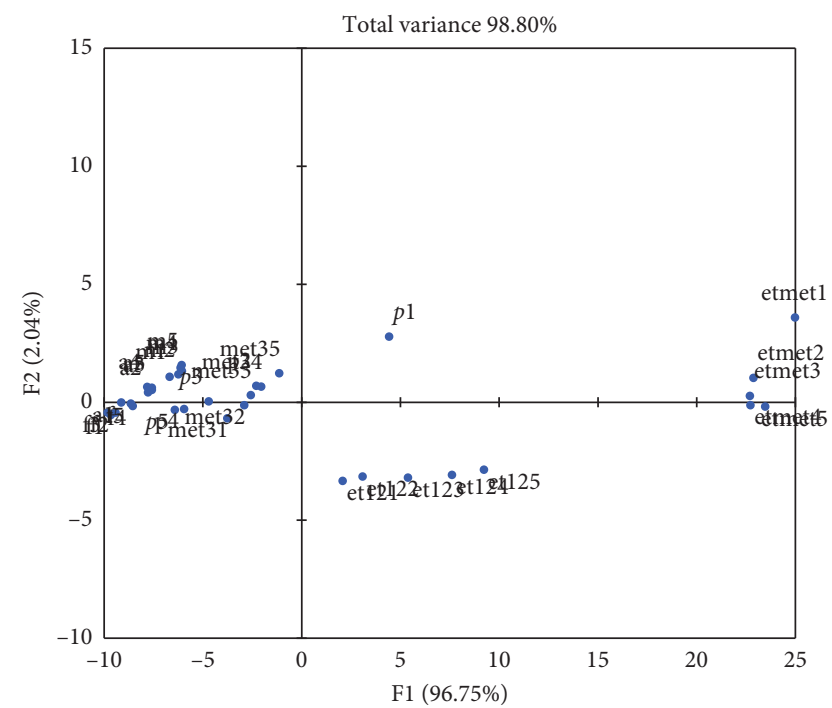

FIGURE 9: PCA of wine volatile compounds obtained using an e-nose with sensors doped with a mixture of palladium and platinum at $0.1 \%$.

Zeolites are used to improve the selectivity, because this is a problem that common sensors usually have to face, that is, a mixture in which other molecules can interfere, such as water:

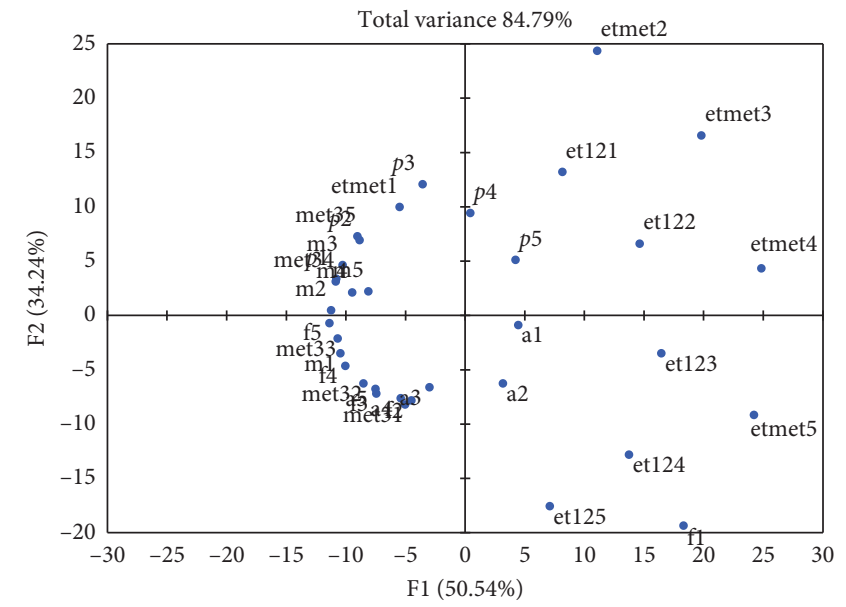

FIGURE 10: PCA of wine volatile compounds obtained using an e-nose with sensors doped with a mixture of palladium and platinum at $0.2 \%$.

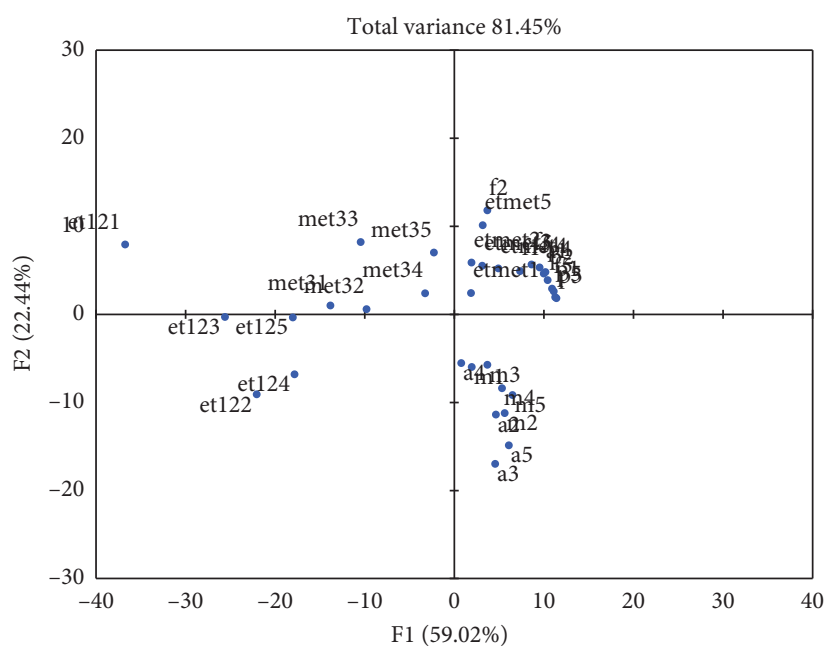

Figure 11: PCA of wine volatile compounds obtained using an e-nose with sensors doped with palladium and/or platinum with zeolite $\mathrm{Y}$ at $0.1 \%$ and $0.2 \%$.

(1) On the one hand, there is the action of the zeolites as molecular sieves. In this case, the fact that zeolites are crystalline solids with fixed-dimension channels can be used to exclude molecules whose sizes are larger than that of the zeolite pore

(2) On the other hand, zeolites are capable of having specific interactions with some molecules of the 
gaseous mixture, using mainly selective adsorption mechanisms.

Zeolite $\mathrm{Y}$ consists of a skeleton of $\mathrm{SiO}_{4}$ and $\mathrm{AlO}_{4}$ tetrahedral bonded by oxygen atoms, as mentioned above. Its chemical formula is $0.9 \hat{\mathrm{A}} \pm 0.2 \quad \mathrm{Na}_{2} \mathrm{O}: \mathrm{Al}_{2} \mathrm{O}_{3}: w \mathrm{SiO}_{2}$ : $x \mathrm{H}_{2} \mathrm{O}$, where $w$ is a value ranging from 3 to 6 , while $x$ represents values higher than 9 .

In general, the method was accepted, especially in the case of zeolite-modified sensors, and we can trust the results due to low correlations as well as the low values of the square cosines.

Previous studies [12] showed that zeolite has a high catalytic activity to convert ethanol to ethylene since it possesses acidic sites that allow the protonation of the $\mathrm{OH}$ group of ethanol. However, this catalytic activity is not as significant as those showed by H-FER and H-MFI.

It is very likely that for the case of ethanol (the molecule with which the zeolite-modified sensor increases its sensitivity), there is a donation of a proton from the acid site of the zeolite to ethanol, causing an electron release to the surface of the semiconductor oxide and an increase of the conduction.

\section{Conclusions}

The electronic nose allowed classifying the aroma components such as ethanol and organic acids, among others.

The M2 $0.1 \%$ (yin oxide doped with a mixture $0.50 \mathrm{Pd} /$ $0.50 \mathrm{Pt}$, at $0.1 \%$ of metals) showed a very good sensitivity as much as that of the oxide $0.1 \% \mathrm{Pt}$.

The sensors array modified with zeolite $\mathrm{Y}$ showed a good performance.

We can conclude that a good differentiation of volatile compounds of wine aromas can be obtained from a nose with 4 sensors, in spite of its simplicity. It is possible to affirm that this sensor array could be applied to differentiate samples of a wine or a group of wines.

The multivariate data analysis, PCA, allowed interpreting the results.

\section{Data Availability}

The authors declare that the data are not included because it belongs exclusively to the project 159-2015-FONDECYT, which is sponsored by CONCYTEC-FONDECYT.

\section{Conflicts of Interest}

The authors declare that there are no conflicts of interest regarding the publication of this paper.

\section{Acknowledgments}

The authors thank the Ciencia Activa-CONCYTEC (Proyecto 159-2015-FONDECYT), Pontificia Universidad Católica del Perú, and Universidad Nacional de Ingeniería for their valuable support and interest in our research.

\section{References}

[1] Y. Zou, H. Wan, X. Zhang, D. Ha, and P. Wang, "Electronic nose and electronic tongue," in Bioinspired Smell and Taste Sensors, Science Press, Beijing, China, 2015.

[2] A. L. Paredes Doig, M. D. R. Sun Kou, G. Picasso Escobar, E. Doig Camino, and G. Comina, "Implementación y evaluación de una nariz electrónica para la detección de alcoholes lineales," Revista Colombiana de Química, vol. 45, no. 2, pp. 12-18, 2016.

[3] A. L. Paredes Doig, M. R. Sun Kou, G. Picasso Escobar, E. Doig Camino, and A. La Rosa-Toro Gómez, "Preparación, caracterización y aplicaciónde sensores de Pd-SnO como nariz electrónica en la clasificación de vinosperuanos y su comparación con técnicas cromatográficas," Revista Colombiana de Química, vol. 47, no. 1, pp. 41-49, 2018.

[4] M. Vilaseca, J. Coronas, A. Cirera, A. Cornet, J. R. Morante, and J. Santamaria, "Development and application of micromachined $\mathrm{Pd} / \mathrm{SnO}_{2}$ gas sensors with zeolite coatings," Sensors and Actuators B: Chemical, vol. 133, no. 2, pp. 435-441, 2008.

[5] I.-S. Kang, H.-M. So, G.-S. Bang, J.-H. Kwak, J.-O. Lee, and C. Won Ahn, "Recovery improvement of graphene-based gas sensors functionalized with nanoscale heterojunctions," Applied Physics Letters, vol. 101, no. 12, article 123504, 2012.

[6] G. M. Silva, E. H. d. Faria, E. J. Nassar, K. J. Ciuffi, and P. S. Calefi, "Synthesis of indium tin oxide nanoparticles by a nonhydrolytic sol-gel method," Química Nova, vol. 35, no. 3, pp. 473-476, 2012.

[7] M. Choudhary, V. N. Mishra, and R. Dwivedi, "Solid-state reaction synthesized $\mathrm{Pd}$-doped tin oxide thick film sensor for detection of $\mathrm{H}_{2}, \mathrm{CO}$, LPG and $\mathrm{CH}_{4}$," Journal of Materials Science: Materials in Electronics, vol. 24, no. 8, pp. 2824-2832, 2013.

[8] K.-C. Lee, Y.-J. Chiang, Y.-C. Lin, and F.-M. Pan, "Effects of $\mathrm{PdO}$ decoration on the sensing behavior of $\mathrm{SnO}_{2}$ toward carbon monoxide," Sensors and Actuators B: Chemical, vol. 226, pp. 457-464, 2016.

[9] C. Liewhiran, N. Tamaekong, A. Wisitsoraat, A. Tuantranont, and S. Phanichphant, "Ultra-sensitive $\mathrm{H}_{2}$ sensors based on flame-spray-made Pd-loaded $\mathrm{SnO}_{2}$ sensing films," Sensors and Actuators B: Chemical, vol. 176, pp. 893-905, 2013.

[10] B. Russell, H. Davis, A. Afonja et al., "Zeolite modified gas sensors for environmental monitoring," in Proceedings of the Conference Paper published 2008 in ECS Transactions, Gramado, Brazil, September 2008.

[11] K. J. Mohan, K. Jagadeesan, and A. Yadav, "A novel approach for zeolite-based materials for gas sensors," IOSR Journal Of Environmental Science, Toxicology And Food Technology, vol. 6, no. 4, pp. 1-5, 2013.

[12] J. C. Soh, S. L. Chong, S. S. Hossain, and C. K. Cheng, "Catalytic ethylene production from ethanol dehydration over non-modified and phosphoric acid modified zeolite H-Y (80) catalysts," Fuel Processing Technology, vol. 158, pp. 85-95, 2017. 

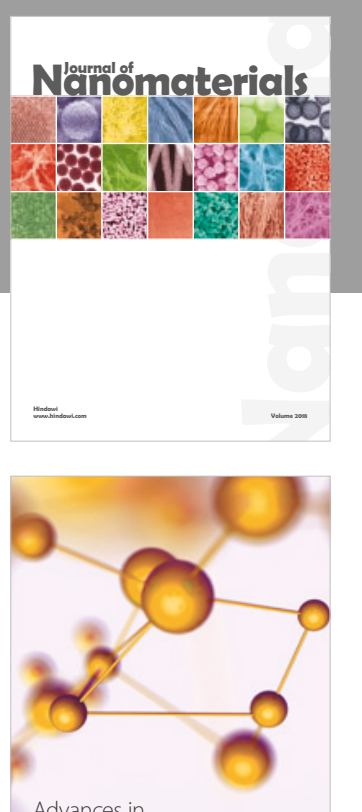

Physical Chemistry
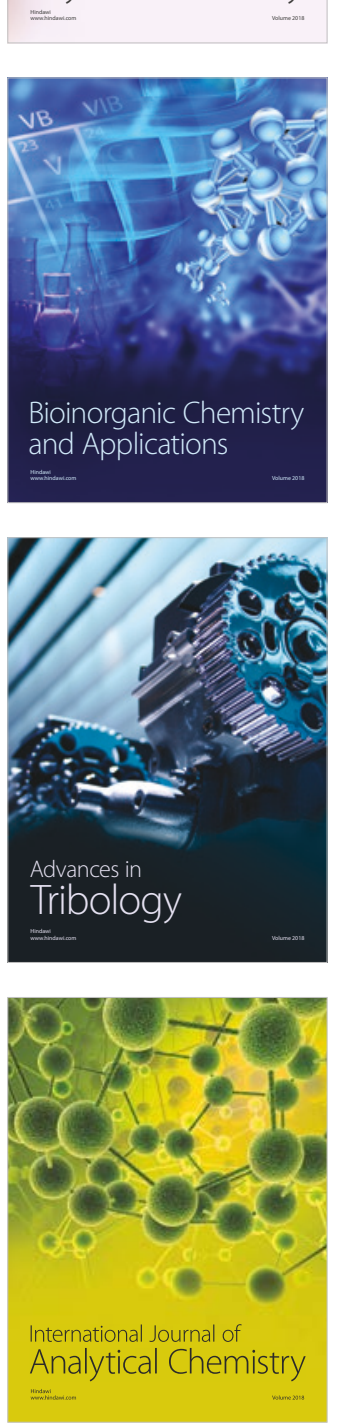

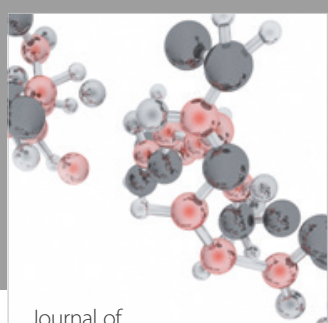

Analytical Methods

in Chemistry

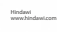

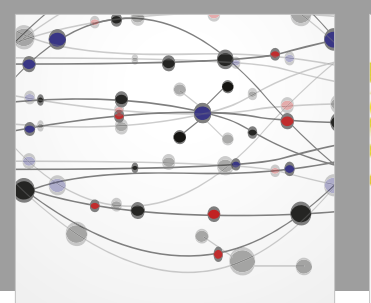

The Scientific World Journal

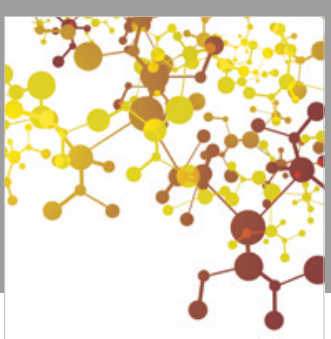

Journal of

Applied Chemistry
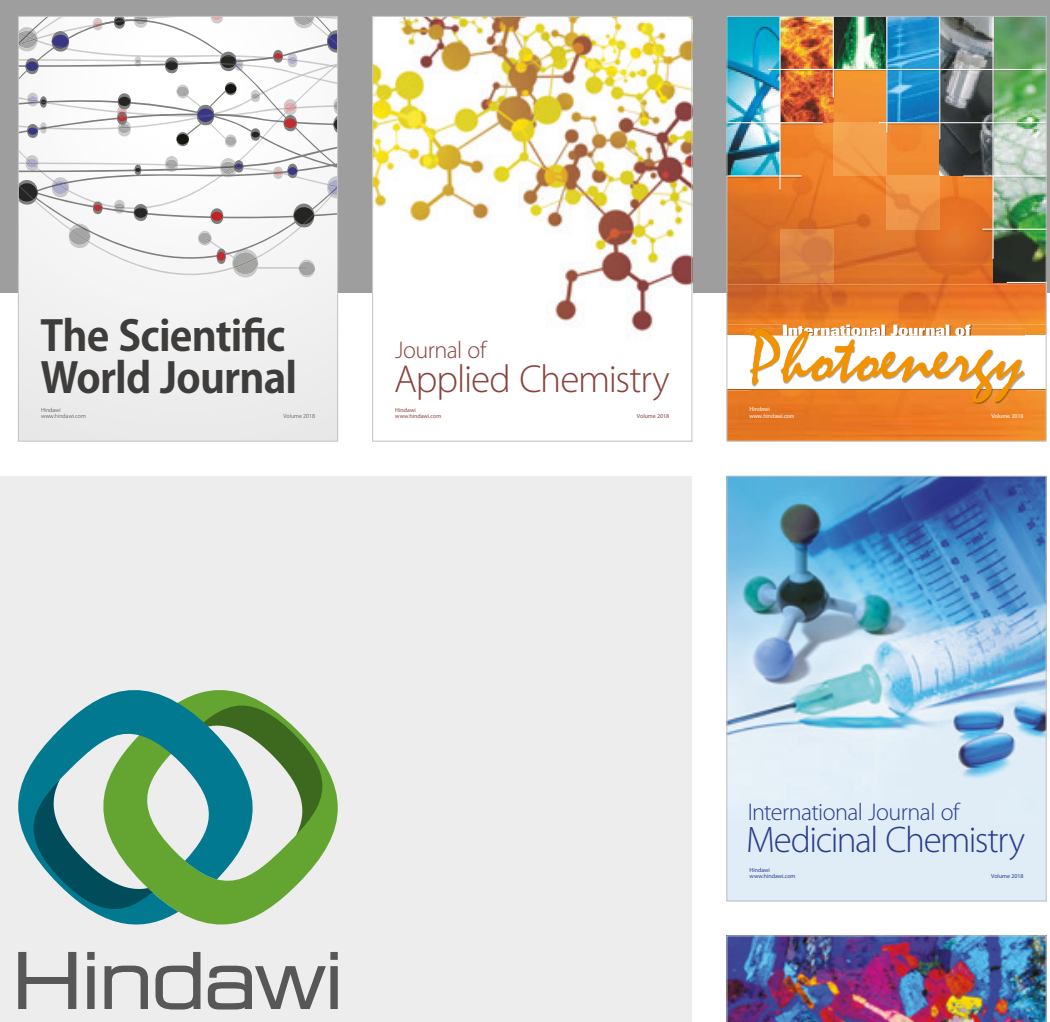

Submit your manuscripts at

www.hindawi.com
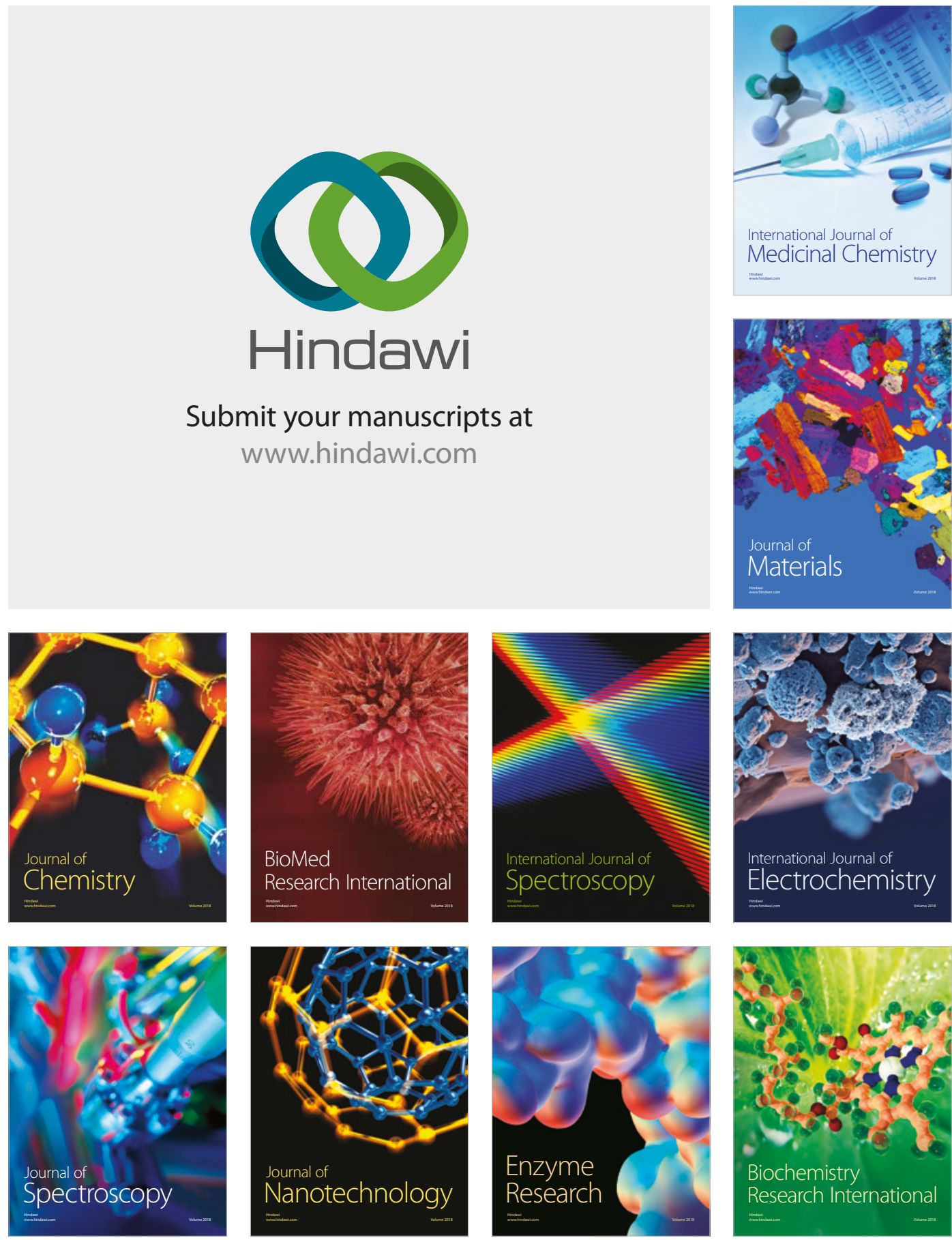
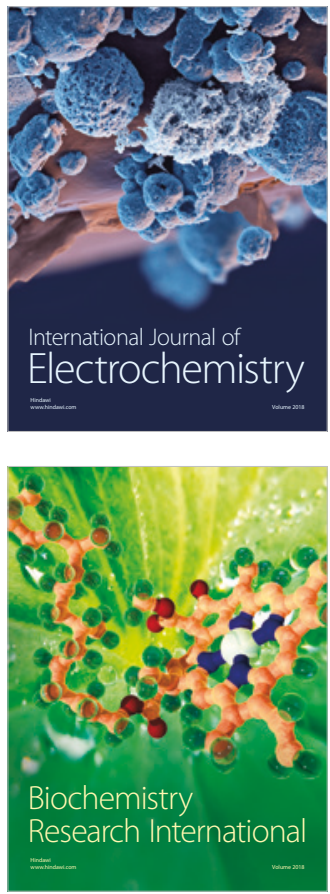